\title{
Growth in Area Coverage and Production Under Organic Farming in India
}

\author{
Heena $^{1 *}$, D.P. Malik ${ }^{2}$ and Nitin Tanwar ${ }^{3}$ \\ ${ }^{1}$ Faculty of Agricultural Sciences, SGT University, Gurugram, Haryana, India \\ ${ }^{2}$ Department of Agricultural Economics, CCS Haryana Agricultural University, Hisar, Haryana, India \\ ${ }^{3}$ Department of Statistics, Lady Shree Ram College for women, University of Delhi, Delhi, India \\ "Corresponding author: heenathaiya1@gmail.com (ORCID ID: 0000-0003-2555-1338)
}

Received: 26-09-2021

Revised: $19-11-2021$

Accepted: 14-12-2021

\begin{abstract}
Organic agriculture is a unique production management technique that fosters and increases agroecosystem health, including biodiversity, biological cycles, and soil biological activity, while excluding all synthetic off-farm inputs. This research uses time series data on area, production, and trade from 2009 to 2021 to examine the growth and trajectory of organic production in India. To make reliable judgments, descriptive statistics such as percentage, average, and compound growth rates were calculated. Organic farming is becoming increasingly popular around the world. In the year 2019, over 72.28 million ha of agricultural land were managed organically by almost 3.13 million growers around the world. India boasts the world's greatest number of organic farmers. At the moment, the total cultivated area (organic + in-conversion) is 2.65 million hectares, with 3.47 million tonnes of organic production coming from the total cultivated area. India is a major exporter of organic products to many countries around the world. During 2020-21, a total of 888180 metric tonnes was exported. As demand for organic products grows in both the local and international markets, organic food enterprises have plenty of room to expand and create cash to help the Indian farm economy.

\section{HIGHLIGHTS}

( In the year 2019, over 72.28 million ha of agricultural land were managed organically by almost 3.13 million growers around the world.

( India has the highest number of organic producers in the world and is a major exporter of organic products.

(0) Area covered under organic farming in India is 2.65 million ha.

0 During 2020-21, a total of 888180 metric tonnes was exported by India.
\end{abstract}

Keywords: Organic producers, area coverage, organic production, export

In India, the green revolution began in the late 1960s. The rapid adoption of high yielding cultivars, combined with increasing agrochemical use and enhanced irrigation systems, resulted in a massive increase in food grain production in the country. At this time, India had attained food grain selfsufficiency and is able to export food grains, particularly wheat and rice. The increased use of chemical fertilizers and plant protection chemicals as a result of continued adoption of modern technologies has resulted in a variety of negative consequences, including deterioration of soil health, heavy weed infestation, severe insect-pest and disease incidence, depletion and contamination of ground water, and so on. Improved agricultural practices, combined with widespread use of chemical synthetic materials, had a severe influence

How to cite this article: Heena, Malik, D.P. and Tanwar, N. (2021). Growth in Area Coverage and Production Under Organic Farming in India. Economic Affairs, 66(04): 611-617.

Source of Support: None; Conflict of Interest: None (C) 
on agricultural production and human health. In this context, organic farming is one of the options for improving soil health and crop productivity. Organic agriculture, according to the FAO, is a unique production management system that promotes and enhances agro-ecosystem health, including biodiversity, biological cycles, and soil biological activity, by using on-farm agronomic, biological, and mechanical methods instead of synthetic off-farm inputs. The organic farming involves IPM and INM practices like use of biopesticides, bio-fertilizers and vermi-compost. The other components of organic farming are crop rotation, inter-cropping, and green manuring (Reddy et al. 2010). Organic farming is cost-effective for farmers since it avoids the use of chemicals (due to their high cost) and instead relies on lowcost alternatives such as biological resources rather than chemical fertilizers and insecticides (Singh et al. 2006). There are numerous economic potential for increasing the added value of organic crops through processing and marketing activities, as well as improving long-term food security. To encourage organic farming in India, the government launched the National Program for Organic Production (NPOP) in 2000. NPOP aims at establishing national standards for organic products, based on IFOAM standards, it collects, analyze, document and disseminate information and knowledge on organic farming and build capacity of individuals and institutions besides advocacy, networking and consultancy services (Aulakh and Ravisankar, 2017). Recently, the Paramparagat Krishi Vikas Yojana (PKVY) has begun to promote numerous interventions to encourage farmers to adopt organic farming throughout the country and to facilitate organic product certification.

\section{MATERIALS AND METHODS}

This paper is based on secondary data, information related to number of organic producers, area coverage under organic farming, production and export of various organic products for Indian and at global level were collected from the published sources such as publications of European union, International Federation of Organic Farming Movements (IFOAM), International Trade Centre (ITC), National Programme of Organic Production (NPOP), APEDA (Agricultural processed food products \& export development Authority), International competence center for organic agricultural (ICCOA), National center of organic farming (NCOF), Reports, Journals, periodicals and newspapers etc. The present study analyzed the trend in area and production of organic using descriptive statistics like average, percentage etc. The compound annual growth rates (CAGR) were estimated using the exponential regression model to examine the trends in area, production and export of organic products in India.

The CAGR calculated to indicate the trends in area, production and export was as under:

$$
Y=A B^{t} U_{t}
$$

Taking $\log$ i.e.

$$
\log Y=\log A+t \log B+\log U_{t}
$$

Where,

$Y=$ area, or production or export,

$A=$ constant

$B=$ regression coefficient,

$U_{t}=$ disturbance term,

$t=$ time in years starting from the base year

The CAGR was computed by using the formula:

$$
r=\{\operatorname{antilog}(b)-1\} \times 100
$$

\section{RESULTS}

\section{Status of organic farming at global level}

Organic farming is becoming increasingly popular around the world. In the year 2019, over 72.28 million ha of agricultural land were managed organically by almost 3.13 million growers around the world (FiBL-IFOAM). For the years 2000 to 2017, the compound annual growth rates (CAGRs) of area under organic farming in various regions were calculated, to eliminate fluctuations, the numbers were obtained on a triennium-ending basis (threeyear average). With a rate of 10.30 percent each year, the CAGR for organic area in the world indicated an upward trend (Table 1). Asia had the highest CAGR of $18.80 \%$, followed by Africa $(16.14 \%)$, Oceania $(9.02 \%)$, and Europe (9.02\%). 
Table 1: Area under organic cultivation in the world: 2000-2017 (million ha)

\begin{tabular}{llllllll}
\hline $\begin{array}{l}\text { Year (Triennium } \\
\text { average) }\end{array}$ & Europe & Africa & Asia & $\begin{array}{l}\text { Latin } \\
\text { America }\end{array}$ & $\begin{array}{l}\text { Northern } \\
\text { America }\end{array}$ & Oceania & World \\
\hline $2000-02$ & $5.31(30.65)$ & $0.20(1.15)$ & $0.30(1.74)$ & $4.73(27.23)$ & $1.19(6.89)$ & $5.63(32.41)$ & $17.38(100)$ \\
$2003-05$ & $6.60(32.05)$ & $0.45(2.20)$ & $2.31(11.25)$ & $5.41(26.26)$ & $1.78(8.65)$ & $11.76(57.10)$ & $20.59(100)$ \\
$2006-08$ & $7.80(24.33)$ & $0.81(2.53)$ & $3.08(9.63)$ & $5.92(18.48)$ & $2.22(6.92)$ & $12.20(38.08)$ & $32.05(100)$ \\
$2009-11$ & $9.93(27.42)$ & $1.05(2.90)$ & $3.24(8.95)$ & $7.38(20.39)$ & $2.71(7.49)$ & $11.89(32.83)$ & $36.22(100)$ \\
$2012-14$ & $11.43(26.66)$ & $1.20(2.81)$ & $3.39(7.92)$ & $6.83(15.92)$ & $2.84(6.62)$ & $17.18(40.07)$ & $42.89(100)$ \\
$2015-17$ & $13.58(22.83)$ & $1.84(3.09)$ & $4.99(8.39)$ & $7.49(12.55)$ & $3.10(5.22)$ & $28.49(47.90)$ & $59.49(100)$ \\
\hline CAGR(\%) & 6.51 & 16.14 & 18.80 & 3.22 & 6.37 & 9.02 & 10.30 \\
\hline
\end{tabular}

Figures in parentheses indicate the percentage to the total organic area in the world. (Source: FiBL Statistics, 2021).

Table 2: Status of organic producers in the world by region: 2000-2017 (Number)

\begin{tabular}{llllllll}
\hline $\begin{array}{l}\text { Year } \\
\text { (Triennium } \\
\text { average) }\end{array}$ & Europe & Africa & Asia & $\begin{array}{l}\text { Latin } \\
\text { America }\end{array}$ & $\begin{array}{l}\text { Northern } \\
\text { America }\end{array}$ & Oceana & World \\
\hline $2000-02$ & 165054.67 & 29925.33 & 42192.67 & 107834.67 & 10067.00 & 2129.67 & 357204.00 \\
& $(46.21)$ & $(8.38)$ & $(11.81)$ & $(30.19)$ & $(2.82)$ & $(0.6)$ & $(100)$ \\
$2003-05$ & 172935.33 & 113178.67 & 94280.00 & 134194.00 & 11647.00 & 2381.00 & 528616.00 \\
& $(32.71)$ & $(21.41)$ & $(17.84)$ & $(25.39)$ & $(2.2)$ & $(0.45)$ & $(100)$ \\
$2006-08$ & 212806.67 & 439230.00 & 278387.00 & 229974.67 & 14956.67 & 7758.00 & 1183100.33 \\
& $(17.99)$ & $(37.13)$ & $(23.53)$ & $(19.44)$ & $(1.26)$ & $(0.66)$ & $(100)$ \\
$2009-11$ & 272600.33 & 529553.33 & 603941.67 & 290503.63 & 16790.67 & 10378.33 & 1723612.30 \\
& $(15.82)$ & $(30.72)$ & $(35.04)$ & $(16.85)$ & $(0.97)$ & $(0.6)$ & $(100)$ \\
$2012-14$ & 329674.67 & 579470.00 & 771113.33 & 338909.67 & 16641.67 & 20078.33 & 2055636.67 \\
& $(16.04)$ & $(28.19)$ & $(37.51)$ & $(16.49)$ & $(0.81)$ & $(0.98)$ & $(100)$ \\
$2015-17$ & 373248.67 & 752639.67 & 1120731.67 & 459310.33 & 20175.33 & 25375.00 & 2751120.00 \\
& $(13.57)$ & $(27.36)$ & $(40.74)$ & $(16.7)$ & $(0.73)$ & $(0.92)$ & $(100)$ \\
CAGR(\%) & 6.12 & 23.68 & 30.07 & 10.82 & 4.54 & 20.00 & 15.24 \\
\hline
\end{tabular}

Figures in parentheses indicate the percentage to the total number of organic producers in the world.

Asia had the most producers (1.59 million) while Oceania had the fewest (0.02 million) in 2019. The number of organic producers in different regions in the world for the period 2000-02 to 2015-17 is depicted in Table 2. The number of the organic farmers was taken on triennium ending basis (threeyears average). The number of organic producers in the world had showed increase from 0.35 million in TE 2000-02 to about 2.75 million in TE 2015-17. The per annum highest growth rate for organic producers was attained in Asia region (30.07\%) followed by Africa (23.68\%), Oceania (20.00\%), Latin America (10.82\%) and Europe (6.12\%). The lowest CAGR was worked out for the region Northern America i.e., 4.54 per cent. The countries with the highest number of producers were India (13.66 lakh producers), Uganda (2.10 lakh) and Ethiopia (2.03 lakh) in 2019. The number of organic producers increased in all countries as there is sharp increase in area under organic cultivation.

\section{Area under organic cultivation in different zones of India}

The zone wise data for the area under organic farming from the year 2010-11 to 2020-21 is presented in the Table 3. The southern zone of India embraced with the states Andhra Pradesh, Karnataka, Kerala, Tamil Nadu. The Western zone is comprised of Goa, Gujarat, Maharashtra and Rajasthan. The Central zone houses the states Chattisgarh and Madhya Pradesh. The Northern zone includes the states Jammu \& Kashmir, Himachal Pradesh, Punjab, Uttrakhand, 
Table 3: Area under organic cultivation in different zones of India (000'ha)

\begin{tabular}{llllllll}
\hline Zone/ State & Southern Zone & Western Zone & Central Zone & Northern Zone & Eastern Zone & $\begin{array}{l}\text { North Eastern } \\
\text { Zone }\end{array}$ & India \\
\hline $2010-11$ & $42.54(5.47)$ & $303.37(39.02)$ & $298.80(38.43)$ & $78.20(10.06)$ & $30.53(3.93)$ & $23.40(3.01)$ & 777.51 \\
$2011-12$ & $74.79(21.69)$ & $89.14(25.86)$ & $132.87(38.54)$ & $27.95(8.11)$ & $16.58(4.81)$ & $3.94(1.14)$ & 344.75 \\
$2012-13$ & $46.73(9.26)$ & $158.35(31.39)$ & $146.12(28.97)$ & $71.66(14.21)$ & $29.07(5.76)$ & $51.73(10.25)$ & 504.44 \\
$2013-14$ & $61.69(8.53)$ & $211.26(29.22)$ & $236.99(32.78)$ & $89.51(12.38)$ & $52.85(7.31)$ & $69.47(9.61)$ & 723.03 \\
$2014-15$ & $107.93(9.12)$ & $307.01(25.93)$ & $402.7(34.02)$ & $131.41(11.10)$ & $122.74(10.37)$ & $107.81(9.11)$ & 1183.87 \\
$2015-16$ & $152.55(10.24)$ & $447.14(30.01)$ & $472.35(31.70)$ & $142.38(9.56)$ & $144.23(9.68)$ & $119.97(8.05)$ & 1489.93 \\
$2016-17$ & $129.28(8.96)$ & $455.6(31.56)$ & $477.56(33.08)$ & $128.17(8.88)$ & $124.18(8.60)$ & $118.13(8.18)$ & 1443.53 \\
$2017-18$ & $165.58(9.27)$ & $537.42(30.08)$ & $633.92(35.48)$ & $142.76(7.99)$ & $128.81(7.21)$ & $168.1(9.41)$ & 1786.49 \\
$2018-19$ & $176.45(9.10)$ & $582.06(30.03)$ & $695.27(35.87)$ & $152.44(7.86)$ & $129.83(6.70)$ & $184.93(9.54)$ & 1938.22 \\
$2019-20$ & $186.04(8.09)$ & $677.69(29.47)$ & $915.32(39.81)$ & $160.47(6.98)$ & $143.12(6.22)$ & $227.87(9.91)$ & 2299.22 \\
$2020-21$ & $208.54(7.85)$ & $830.89(31.26)$ & $1043.21(39.25)$ & $191.64(7.21)$ & $182.15(6.85)$ & $192.73(7.25)$ & 2657.88 \\
\hline CAGR(\%) & 17.49 & 19.20 & 20.80 & 14.24 & 24.20 & 34.32 & 19.70 \\
\hline
\end{tabular}

Figures in parenthesis indicate the percentage to the total organic area in India; * India includes area under organic farming of 28 States and 8 Union Territories; (Source: APEDA, 2021).

Table 4: Zone wise organic production (cultivated+ in conversion) in India (Lakh tonnes)

\begin{tabular}{llllllll}
\hline Zone/ State & $\begin{array}{l}\text { Southern } \\
\text { Zone }\end{array}$ & $\begin{array}{l}\text { Western } \\
\text { Zone }\end{array}$ & $\begin{array}{l}\text { Central } \\
\text { Zone }\end{array}$ & $\begin{array}{l}\text { Northern } \\
\text { Zone }\end{array}$ & $\begin{array}{l}\text { Eastern } \\
\text { Zone }\end{array}$ & $\begin{array}{l}\text { North Eastern } \\
\text { Zone }\end{array}$ & India \\
\hline $2010-11$ & $3.8(9.78)$ & $11.79(30.33)$ & $12.23(31.46)$ & $6.49(16.70)$ & $2.1(5.40)$ & $2.42(6.23)$ & 38.87 \\
$2011-12$ & $2.62(8.86)$ & $3.81(12.88)$ & $0.86(2.91)$ & $0.58(1.96)$ & $0.5(1.69)$ & $0.18(0.61)$ & 29.58 \\
$2012-13$ & $3.51(26.43)$ & $4.03(30.35)$ & $4.25(32.00)$ & $0.83(6.25)$ & $0.6(4.52)$ & $0.06(0.45)$ & 13.28 \\
$2013-14$ & $2.82(22.95)$ & $4.1(33.36)$ & $3.99(32.47)$ & $0.82(6.67)$ & $0.44(3.58)$ & $0.08(0.65)$ & 12.29 \\
$2014-15$ & $2.9(26.48)$ & $3.39(30.96)$ & $3.26(29.77)$ & $0.88(8.04)$ & $0.39(3.56)$ & $0.09(0.82)$ & 10.95 \\
$2015-16$ & $3.16(23.67)$ & $4.79(35.88)$ & $3.72(27.87)$ & $1.01(7.57)$ & $0.52(3.90)$ & $0.1(0.75)$ & 13.35 \\
$2016-17$ & $1.99(16.86)$ & $3.67(31.10)$ & $3.95(33.47)$ & $1.36(11.53)$ & $0.49(4.15)$ & $0.35(2.97)$ & 11.8 \\
$2017-18$ & $1.97(11.75)$ & $5.49(32.76)$ & $5.81(34.67)$ & $2.07(12.35)$ & $0.85(5.07)$ & $0.54(3.22)$ & 16.76 \\
$2018-19$ & $4.22(16.19)$ & $10.64(40.81)$ & $7.53(28.88)$ & $2.15(8.25)$ & $1.09(4.18)$ & $0.5(1.92)$ & 26.07 \\
$2019-20$ & $1.78(6.57)$ & $11.45(42.27)$ & $9.93(36.66)$ & $2.09(7.72)$ & $1.45(5.35)$ & $0.26(0.96)$ & 27.09 \\
$2020-21$ & $4.26(12.28)$ & $11.51(33.19)$ & $14.12(40.72)$ & $2.81(8.10)$ & $1.48(4.27)$ & $0.78(2.25)$ & 34.68 \\
\hline CAGR (\%) & -1.37 & 7.40 & 12.71 & 5.69 & 5.46 & 6.91 & 1.65 \\
\hline
\end{tabular}

Figures in parentheses indicate the percentage to the total production of organic farming in India; *India includes organic production of 28 States and 8 Union Territories; (Source: APEDA, 2020).

Uttar Pradesh and Haryana. Eastern zone of India includes the states Bihar, Jharkhand, Orissa and West Bengal. The North-eastern zone comprises of the states Arunachal Pradesh, Assam, Manipur, Meghalya, Mizoram, Nagaland, Sikkim and Tripura. This clearly indicated that the area under organic farming in North-eastern zone of India indicated with the highest growth rate of 34.32 percent followed by Eastern zone (24.20\%), Central zone $(20.80 \%)$,Western zone $(19.20 \%)$ Southern zone $(17.49 \%)$, and Northern zone (14.24\%). The overall per annum increase in organic area in the country was at rate of 19.70 per cent annually for the period 2010-2021. These results were also similar with the finding of Gurung et al. (2013), Deshmukh and babar (2015) and Gopinath et al. in their respective studies.

\section{Zone wise organic production (cultivated + in conversion) in India}

Out of the total organic producers in the world approximately half of them are in India. This is mainly because of small holdings with each producer. (Bhardwaj et al. 2019; Bhutani et al. 2018; Bhattacharyya et al. 2005). Zone wise organic production (cultivated + in conversion) is presented in the table 4 . The CAGR of organic production for all the six zones of the country was also calculated and found positive except southern zone with -1.37 
per cent. The highest CAGR was found for central zone $(12.71 \%)$ followed by western zone $(7.40 \%)$, north-eastern zone $(6.91 \%)$, northern zone $(5.69 \%)$ and eastern zone $(5.46 \%)$. The overall per annum increase in organic production in the country was at rate of 1.65 per cent annually for the period 2010-2021. During 2011-12, Odisha had the highest production and yield of organic crops (Deshmukh et al. 2015). There are many products grown organically in the country but the major products grown organically were oilseed crops (7.27 lakh tonnes) and fibre crops (3.12 lakh tonnes) in 201819. With the production of more than $77,000 \mathrm{MT}$ of organic cotton lint India had achieved the status of largest organic cotton grower in the world in the year 2007-08 (Bhardwaj et al. 2019).

\section{Category wise organic production (cultivated + in conversion) in India}

India (28 States and 4 Union Territories), produced around 34.96 lakh tonnes (2020-21) of organic products comprising 34.68 lakh tonnes of certified production, 0.27 lakh tonnes in conversion production and remaining from wild harvest. The organic production includes all varieties of food products namely oilseeds, sugarcane, cereals and millets, cotton, pulses, medicinal plants, tea, fruits, spices, dry fruits, vegetable etc. are presented in Table 5.

During 2020-21, oilseed crop alone produced to tune of 8.53 lakh tonnes, which is 24.60 per cent of the total organic production. The organic production for all the categories of products showed positive growth rate during last seven years (2014-2021). The higher growth rate is observed in case of oilseed crops, which is 31.81 percent followed by spices and condiments $(27.11 \%)$ and fibre crops (24.77). The overall production the country is increased from 10.96 lakh tonnes to 22.43 lakh tonnes with the growth rate of 22.43 percent during the period 2014-2019. Das K. (2007); Chandrakala et al. (2018) also reported in his study that the production is not limited to the edible sector but also produces organic cotton fiber, functional food products etc.

\section{Export of organic agricultural commodities from India}

Indian organic farming industry is almost entirely export oriented, running as contract farming under financial agreement with contracting firms and organic producers. The growing demand for organic produce has opened up new export prospects, and many developing countries have begun to tap into profitable organic export markets. The Indian organic food sector is driven by the growing demand for organic food items in developed countries, as well as the Indian government's considerable support and focus on agri-exports. Mukherjee et al. (2018) observed that there are a number of entrepreneurs had responded positively to government initiatives and several start-ups had been formed in the organic food segment. The channels adopted for the export of organic products, except for tea, are mainly through export companies. Organic tea is produced by major well organized tea estates which are exporting tea directly. In the case of other organic products, predominantly small farmers are involved in producing organic products. Hence,

Table 5: Category-wise organic production in India (lakh ones)

\begin{tabular}{llllllllll}
\hline S1. No. Category & $\mathbf{2 0 1 4 - 1 5}$ & $\mathbf{2 0 1 5 - 1 6}$ & $\mathbf{2 0 1 6 - 1 7}$ & $\mathbf{2 0 1 7 - 1 8}$ & $\mathbf{2 0 1 8 - 1 9}$ & $\mathbf{2 0 1 9 - 2 0}$ & $\mathbf{2 0 2 0 - 2 1}$ & CAGR (\%) \\
\hline 1 & Sugar crops & $3.38(30.84)$ & $5.32(39.82)$ & $2.82(23.88)$ & $3.18(19.11)$ & $9.84(37.95)$ & $3.35(12.37)$ & $7.97(22.98)$ & 10.91 \\
2 & Oilseed crops & $2.28(20.80)$ & $2.52(18.86)$ & $3(25.40)$ & $5.39(32.39)$ & $7.27(28.04)$ & $10.69(39.46)$ & $8.53(24.60)$ & 31.81 \\
3 & Fibre crops & $2.09(19.07)$ & $1.64(12.28)$ & $1.55(13.12)$ & $2.47(14.84)$ & $3.12(12.03)$ & $3.35(12.37)$ & $8.11(23.39)$ & 24.77 \\
4 & $\begin{array}{l}\text { Cereals and } \\
\text { millets }\end{array}$ & $1.6(14.60)$ & $2.06(15.42)$ & $1.96(16.60)$ & $2.84(17.07)$ & $2.69(10.37)$ & $2.71(10.00)$ & $3.21(9.26)$ & 11.13 \\
& & & & & & & & \\
5 & Pulses & $0.35(3.19)$ & $0.39(2.92)$ & $0.62(5.25)$ & $0.67(4.03)$ & $0.71(2.74)$ & $0.7(2.58)$ & $0.91(2.62)$ & 16.07 \\
7 & Spices and & $0.18(1.64)$ & $0.24(1.80)$ & $0.37(3.13)$ & $0.46(2.76)$ & $0.56(2.16)$ & $0.47(1.73)$ & $0.94(2.71)$ & 27.11 \\
& Condiments & & & & & & & & \\
10 & Dry fruits & $0.07(0.64)$ & $0.09(0.67)$ & $0.08(0.68)$ & $0.08(0.48)$ & $0.08(0.31)$ & $0.08(0.30)$ & $0.11(0.32)$ & 4.08 \\
12 & Others & $0.03(0.27)$ & $0.02(0.15)$ & $0.11(0.93)$ & $0.1(0.60)$ & $0.15(0.58)$ & $5.74(21.19)$ & $4.9(14.13)$ & 34.70 \\
\hline
\end{tabular}

Figures in parentheses indicate the percentage to the total production. 
Table 6: Export status of organic commodities from India

\begin{tabular}{lllll}
\hline \multirow{2}{*}{ Year } & \multicolumn{3}{c}{ In quantity term } & In value Term \\
\cline { 2 - 5 } & $\begin{array}{l}\text { Export volume } \\
\text { (tonnes) }\end{array}$ & $\begin{array}{l}\text { Percent change over } \\
\text { previous year }\end{array}$ & $\begin{array}{l}\text { Export value } \\
\text { (Crores) }\end{array}$ & $\begin{array}{l}\text { Percent change over previous } \\
\text { year }\end{array}$ \\
\hline $2002-03$ & 4161 & & 619.60 & \\
$2005-06$ & 7953 & -4.69 & 1281.60 & 34.44 \\
$2009-10$ & 58408 & 31.32 & 526.00 & -2.05 \\
$2013-14$ & 194088 & 17.44 & 2563.08 & 21.66 \\
$2017-18$ & 458339 & 47.96 & 3453.48 & 39.35 \\
$2018-19$ & 614089 & 33.98 & 5150.99 & 49.15 \\
$2019-20$ & 638998 & 4.05 & 4685.90 & -9.02 \\
$2020-21$ & 888179 & 38.99 & 7078.50 & 51.05 \\
\hline CAGR(\%) & 22.44 & & 22.86 & \\
\hline
\end{tabular}

Source: APEDA, 2021.

these products are exported through exporters (Ummyiah, 2017).

Organic food exports from India are increasing with more farmers shifting to organic farming. With the domestic consumption being low, the prime market for Indian organic food industry lies in the US and Europe. India has now become a leading supplier of organic herbs, organic spices, organic basmati rice etc. Table 6 reveals that an export of organic products from India in 2002-03 was 4161 tonnes that went up to 888179 tonnes in 2020-21. Similarly, the export value of organic products was ₹ 619.60 crores in 2002-03 which increased to ₹ 7078.50 crores in 2020-21. The compound growth rate of volume and value of export of organic products was 22.44 and 22.86 percent.

\section{CONCLUSION}

Indian agriculture has mostly evolved as an environmentally friendly method of increasing crop yield utilizing natural resources. Organic product demand is rapidly increasing in nations such as the United States and Germany. Organic farming is becoming increasingly popular around the world. In the year 2019, over 72.28 million ha of agricultural land were managed organically by almost 3.13 million growers around the world. In 2019, India (13.66 lakh producers), Uganda (2.10 lakh), and Ethiopia (2.03 lakh) had the largest number of producers. India's total production in 2020-21 was 34.68 lakh tonnes. When it comes to area, however, 26.58 lakh hectares of land are organically farmed. The organic farming sector in
India is nearly exclusively export-oriented, with contract farming taking place under financial agreements with contracting firms. In 2002-03, India exported 4161 tonnes of organic products, which increased to 888179 tonnes in 2020-21. India has the potential to become a major organic producing country and at the same time increasing health consciousness and increasing disposable income among Indians is ceaselessly increasing the demand for organic food. As a result, a strong national organic policy is critical in the current situation, as it will provide organic farming a prominent place while resolving current difficulties and roadblocks. To understand how policies, programs, and plans in the organic sector affect the existing organic sector, the government must conduct a rigorous and indepth analysis of the overall picture. Based on a study of the state of the organic sector, participatory consultations, a need assessment, and suitable action sequencing, an action plan for the organic sector should be prepared.

\section{REFERENCES}

APEDA 2020. https://www.apeda.gov.in

Bhardwaj, M. and Manisha. 2019. Growth and performance of organic farming in India: what could be the future prospects. J. Cur. Sc., 20(1): 1-9.

Bhattacharyya, P. and Chakraborty, G. 2005. Current status of organic farming in India and other countries. Indian J. Fertilizer, 1(9): 111-123.

Bhutani, S., Kahlon, S. and Monika. 2018. Organic Farming in India: An Alternative Agricultural System. Amity J. Agribusiness, 3(1): 37-49. 
Chandrakala, N. and Deepalakshmi, M. 2018. Success mantra for organic farming - The production and marketing strategy of the organic farmers. Int. J. Pure and Appl. Math., 119(18): 3459-3475.

Das, K. 2007. Towards a smoother transition to organic farming. Eco. and Poli. Weekly, 42: 2243-2245.

Deshmukh, M.S. and Babar. 2015. Present Status and Prospects of Organic Farming in India. European Academic Res., 3(4): 4271-4287.

FAO, 2020. Organic Agriculture, Food and Agriculture Organization of the United Nations, Rome: https://www. fao.org/home/en.

Gopinath, K.A., Srinivasa Rao, Ch., Ramanjaneyulu, A.V., Jayalakshmi, M., Chary, G.R. and Venkatesh, G. 2016. Organic farming research in India: present status and way forward. Int. J. Eco. Plants, 3(3): 98-101.

Gurung, K., Sharma, P. and Dhalor, M. 2013. Comparative study of India's organic agriculture with the leading countries: Europe and U.S.A. IOSR J. Agric. and Vet. Sc., 2(4): 26-39.

IFOAM Organic International. Retrieved March, 2020, from IFOAM: https://www.ifoam.com
Manisha, G. 2016. Organic Farming in India: status, Issues and Prospects. SOPAAN-II, 1(1): 26-36.

Mukherjee, A., Kapoor, A. and Dutta, S. 2018. Organic food business in India: A Survey of Companies. Res. Econ. Manag., 3(2): 72-90.

National programme for organic production, 2018. Published by, Ministry of commerce \& industry Department of commerce, New Delhi.

Reddy, S.B. 2010. Organic Farming: Status, Issues and Prospects - A Review. Agric. Eco. Res. Rev., 23(2): 343-358.

Roychowdhury, R., Gawwad, M.R.A., Banerjee, U., Bishnu, S. and Tah, J. 2013. Status, Trends and Prospects of Organic farming in India: A Review. J. Plant Biology Res., 2(2): 38-48.

Singh, J., Singh, G.P. and Rajkishor. 2006. Present status and Economics of organic farming in the district of Udham Singh Nagar in Uttaranchal. Agric. Eco. Res. Rev., 19: 135-144.

Ummyiah, H.M., Narayan, S., Kumar, P., Nabi, A., Ajaz, M. and Magray, M. 2017. Export of organic products: Opportunities and challenges. J. Pharmacognosy and Phytochemistry, 6(6): 1084-1088. 
